\title{
Mitochondrial DNA sequences in prehistoric human remains from the Alps
}

\author{
Giulietta Di Benedetto ${ }^{1}$, Ivane S Nasidze ${ }^{2,6}$, Michele Stenico ${ }^{1}$, Lorendana Nigro ${ }^{3}$, \\ Matthias Krings ${ }^{4}$, Michele Lanzinger ${ }^{5}$, Linda Vigilant ${ }^{2,6}$, Mark Stoneking ${ }^{2,6}$, Svante \\ Pääbo $^{4,6}$ and Guido Barbujani ${ }^{1}$
}

\begin{abstract}
${ }^{1}$ Dipartimento di Biologia, Università di Ferrara, Italy; ${ }^{2}$ Department of Anthropology, Pennsylvania State University, USA; ${ }^{3}$ Dipartimento di Biologia, Università di Padova, Italy; ${ }^{4}$ Institute of Zoology, University of M unich, Germany;

${ }^{5}$ M useo Tridentino di Scienze Naturali, Trento, Italy
\end{abstract}

The spread of agriculture that started in the Near East about 10000 years ago caused a dramatic change in the European archaeological record. It is still unclear if that change was caused mostly by movement of people or by cultural transformations. In particular, there is disagreement on what proportion of the current European gene pool is derived either from the pre-agricultural, paleolithic and mesolithic people, or from neolithic farmers immigrating from the south-east. To begin to characterise the mtDNA gene pool of prehistoric Europe we examined five human remains from the Eastern Italian Alps, dated between 14000 and 3000 years ago. Three of them yielded sufficient amount of mtDNA for analysis. DNA extracts were prepared in two independent laboratories, and PCR products from the first hypervariable segment of the mtDNA control region were cloned and sequenced. Together with the 5200 year old 'ice man', these DNA sequences show that European mtDNA diversity was already high at the beginning of the neolithic period. All the neolithic sequences have been observed in contemporary Europeans, suggesting genealogical continuity between the neolithic and present-day European mtDNA gene pool. The mtDNA sequence from a 14000 year-old specimen was not observed in any contemporary Europeans, raising the possibility of a lack of continuity between the mesolithic and present-day European gene pools. European Journal of Human Genetics (2000) 8, 669-677.

Keywords: mitochondrial DNA; ancient DNA; genetic diversity; paleolithic; neolithic

\begin{abstract}
Introduction
The first modern human inhabitants of Europe moved in from the Near East in the upper paleolithic era, approximately 45000 years ago, ${ }^{1}$ ultimately replacing the resident Neandertals a little after 30000 years ago. ${ }^{2}$ They came to occupy a large portion of the continent, but probably had to withdraw into a few warmer areas, or glacia refugia, during the last glaciation, some 18000 years ago, ${ }^{3}$ from which they may have re-expanded during the postglacial, mesolithic period. About 10000 years ago, demographic growth
\end{abstract}

Correspondence: Guido Barbujani, Department of Biology, University of Ferrara, via L Borsari 46, I-44100 Ferrara, Italy. Tel: +390532 291312; Fax: +390532 249761; E-mail: bjg@dns.unife.it

${ }^{6}$ Current address: Max Planck Institute for Evolutionary Anthropology, Leipzig, Germany

Received 10 December 1999; revised 27 March 2000; accepted

18 April 2000 prompted by the development of food-producing technologies led to a westward and northward dispersal of Near Eastern neolithic farmers.

It is not well established whether the transition from a (paleolithic and mesolithic) food-collecting economy to a (neolithic) food-producing economy involved an extensive movement of people from the areas where farming first appeared, or if agricultural technologies spread mainly by cultural transmission. In particular, opinions differ on the impact of neolithic phenomena on the mitochondrial gene pool of Europe. Some authors ${ }^{4-8}$ have claimed that most of the current mtDNA gene pool is derived from the upper paleolithic colonisers, whereas according to others ${ }^{9-17}$ much of the current European gene pool entered Europe only with the arrival of the neolithic farmers, who largely replaced previous mesolithic inhabitants. 
MtDNA sequences from ancient remains should shed further light on this controversy. To begin to characterise the mtDNA gene pool of prehistoric Europe, we analysed the DNA extracted from the remains of five individuals found in the Eastern Italian Alps. These remains are between 14000 and 3000 years old, and come from a region where three languages, German, Italian and Ladin, are spoken within a few tens of kilometres. Artefacts documenting agricultural activities are dated in the Alps to around 7000 years ago or less, ${ }^{18}$ so these remains span the time when agriculture spread to this region. Two different laboratories independently extracted and sequenced the first hypervariable mtDNA control region from the only three individuals who yielded suitable amounts of DNA. The analysis of the sequences thus obtained shows that the sequences from neolithic remains also occur in contemporary Europeans, while the mesolithic sequence has not been observed to date in any individual.

\section{Materials and methods Samples}

We investigated samples (bones and/or teeth) from five individuals, dated between 3000 and 13000 years BP (see Results, Table2 for further details), and retrieved near the valleys where Ladin is currently spoken (Figure1).

\section{Testing for racemisation}

Each sample was first analysed for the degree of amino acid racemisation, which is a useful proxy measure of DNA preservation. ${ }^{19}$ Samples of $10 \mathrm{mg}$ of tooth or bone powder were hydrolysed as described by Poinar et $\mathrm{al}^{1}{ }^{19}$ and analysed by HPLC.

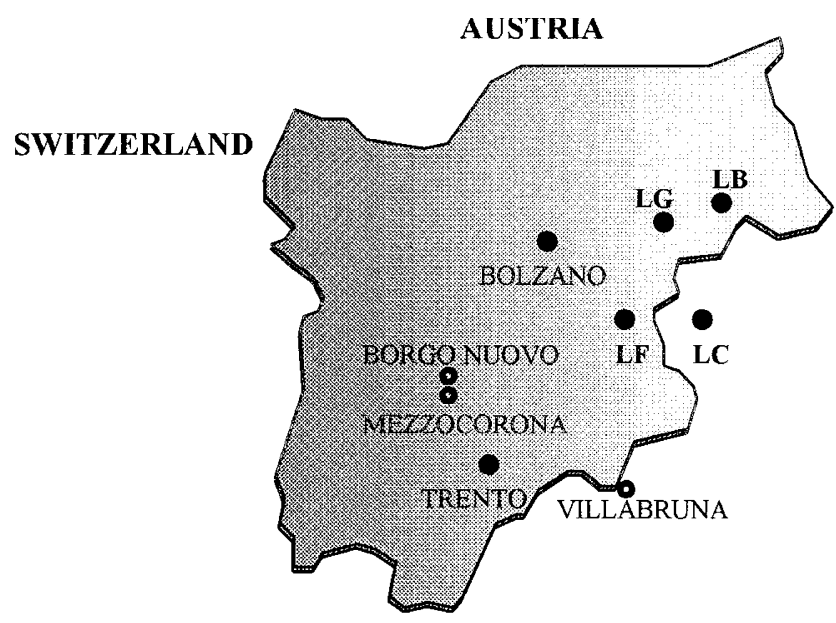

Figure 1 Distribution of the specimens. Distribution of the ancient specimens analysed in this study (open circles) and of the present-day samples studied in the same area (solid circles $^{29,33}$ in Trentino-South Tyrol, north-eastern Italy. Trento, Bolzano: Italian speakers; LB, LC, LF, LG: Ladin speakers from Badia valley, Colle Santa Lucia, Fassa valley and Gardena valley, respectively.

\section{Extraction}

To minimise the risk of contamination, the entire process of DNA extraction and PCR amplification was carried out in a dedicated room into which no modern, amplified or cloned DNA was ever taken, where all personnel wore disposable lab coats, face shields and gloves, and where strict cleaning criteria were followed (frequent treatment with bleach and UV light).

Teeth were divided into crown and root portions by means of a drill saw; the root surface was then removed, the whole root was powdered in a grinding-mill and DNA was extracted using a silica-based protocol, as described by Kings et al. ${ }^{20}$ All samples that proved suitable for DNA analysis were extracted three times, twice in the Munich laboratory and once, independently and using a different tooth from the same individual, in the Penn State laboratory. All the subsequent amplification and sequencing stages were carried out on each extract independently between laboratories and using partly different methods (see Different procedures in the two laboratories).

\section{PCR, cloning and sequencing}

The mtDNA hypervariable region I (HVRI) sequence (360 bp) was reconstructed from five overlapping amplification products using previously published primers. ${ }^{21}$ All the amplification reactions were set up according to a 'hot start' protocol. ${ }^{20}$ Ten $\mu \mathrm{l}$ of the reaction products were electrophoresed in $3 \%$ agarose gels, stained with ethidium bromide and visualised by UV light. Five $\mu$ I of the amplification products were used in $50 \mu \mathrm{l}$ reamplification reactions $(67 \mathrm{~mm}$ Tris- $\mathrm{HCl}$ [pH 8.8], $2 \mathrm{mM} \mathrm{M} \mathrm{gCl}, 2 \mathrm{mg} / \mathrm{ml} \mathrm{BSA}, 1 \mu \mathrm{M}$ of each primer and $0.125 \mathrm{~mm}$ of each dNTP, 0.75 units Taq DNA polymerase). Thirty cycles identical to the initial amplification, except for an increase of $3^{\circ} \mathrm{C}$ in annealing temperature, were performed. If primer dimers or non-specific bands were visible upon gel electrophoresis, reamplification products were gel purified prior to cloning. Alternatively, $10 \mu \mathrm{l}$ of the reamplification volume were directly treated with T4 DNA polymerase (New England Biolabs, Beverly, MA, USA) according to the supplier's protocol and ligated into a Smal-cut pUC18 (Pharmacia Biotech, Uppsala, Sweden) vector in the presence of 10 units of Smal at ambient temperature for $16 \mathrm{~h}$. E. coli SURE (Strategene, La Jolla, CA, USA) were performed by electroporation using half of the ligation reaction, and grown in $1 \mathrm{ml} \mathrm{SOC}$ medium ${ }^{22}$ for $20-25$ min before plating on selective IPTG/X-gal agar plates. White colonies were transferred into $12.5 \mu \mathrm{l}$ PCR reactions (contents as in reamplifications) with 'M13 universal' and 'M13 reverse' primers. After $5 \mathrm{~min}$ at $92^{\circ} \mathrm{C}, 30 \mathrm{cycles}$ of PCR $\left(30 \mathrm{~s}\right.$ at $90^{\circ} \mathrm{C}, 1 \mathrm{~min}$ at $50^{\circ} \mathrm{C}, 1 \mathrm{~min}$ at $72^{\circ} \mathrm{C}$ ) were carried out and clones with inserts of the expected size were identified by agarose gel electrophoresis. These clones were sequenced with the Thermo Sequenase kit (Amersham Biotech, Uppsala, Sweden) according to the supplier's instructions, and half of the sequencing reactions was loaded on to a $6 \%$ denaturing polyacrylamide gel and 
analysed on an A.L.F. automated sequencer (Pharmacia Biotech, Uppsala, Sweden).

\section{Quantitative PCR}

To determine the approximate number of template molecules in the extracts, we set up a quantitative PCR experiment, in which a dilution series of a competitor template with known concentration was added to a constant amount of extract. The competitor standard used, previously constructed by Handt et al $^{23}$ (see also Forster ${ }^{24}$ ), was already available in the Munich laboratory. The standard and the DNA extracted from the samples were used in hot-start amplifications with the primers $\mathrm{H} 16271$ and L16209, ${ }^{21}$ giving, respectively, products of $81 \mathrm{bp}$ and $103 \mathrm{bp}$.

\section{Different procedures in the two laboratories}

Some reactions took place under slightly different conditions in the Penn State laboratory, namely:

(i) teeth were soaked in $10 \%$ bleach for 10 minutes, and rinsed with $70 \%$ ethanol after removing the surface;

(ii) amplifications were carried out using AmpliTaqGold (Perkin Elmer Corporation, Foster City, CA, USA) for 50 cycles with a denaturation temperature of $95^{\circ} \mathrm{C}$;

(iii) a different cloning kit was used (Original TA Cloning Kit with pCR2.1, Invitrogen, Groningen, The Netherlands); and (iv) sequences were determined by cycle sequencing reactions (DNA Sequencing Kit, Perkin Elmer Corporation, Foster City, CA, USA) using an ABI 373 automated DNA sequencer (Perkin Elmer Corporation, Foster City, CA, USA).

\section{Results}

Post-mortem changes to tissues cause racemisation of the L-amino acids (the only ones incorporated in protein synthesis), resulting in a mixture of $L$ and $D$ enantiomers. It has been shown that a relationship exists between the extent of amino acid racemisation and the successful retrieval of authentic DNA from an ancient specimen. ${ }^{19}$ Aspartic acid (Asp) is perhaps the best indicator of the state of DNA preservation, probably because depurination is one major process responsible for DNA degradation, and the activation energy and racemisation rate of Asp are similar to those of DNA depurination. Since the racemisation rate for alanine (Ala) and leucine (Leu) is lower than that for Asp, the ratio of the two enantiomers of Ala and Leu has been considered to be an indicator of the contamination level of the sample analysed. Thus, values of D/L Ala and D/L Leu higher than $D / L$ Asp values should be interpreted as a sign of contamination by exogenous amino acids.

Table1 shows the racemisation levels for the five samples. Values of D/L Asp vary between 0.074 and 0.117 , all compatible with potential DNA recovery. ${ }^{19,20}$ In all cases D/L Ala and D/L Leu (when determined) are lower than D/L Asp,

Table 1 Results of the HPLC evaluation of the amount and D/L ratio of some amino acids in the five samples analysed

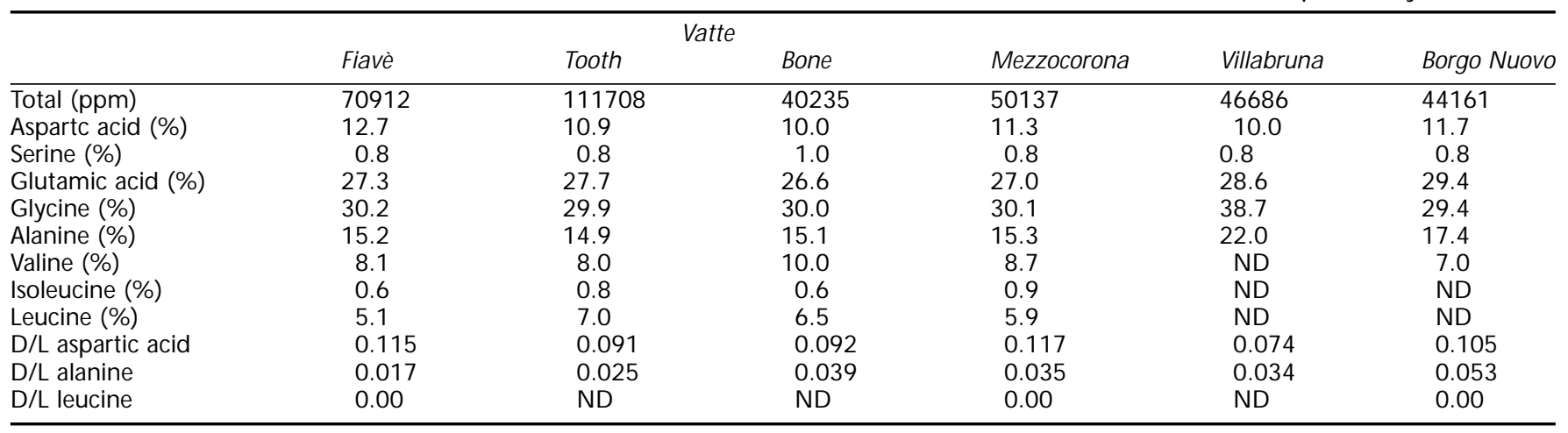

Table 2 Summary of the results of the extraction and quantitation experiments

\begin{tabular}{llll}
\hline Sample & Age $^{\mathrm{a}}$ & DNA extraction & Approximate no. of template molecules in an amplification \\
\hline Fiavè & Neolithic $^{\mathrm{b}}$ & - & some hundreds \\
Vatte & $8365-8990^{\mathrm{c}}$ & + & some thousands (between 4000 and 20000) \\
Mezzocorona & $6326-6444^{\mathrm{d}}$ & + & some thousands (between 4000 and 20000) \\
Villabruna & $13831-14267^{\mathrm{c}}$ & + & some thousands (between 4000 and 20000) \\
Borgo Nuovo & $5930-6240^{\mathrm{e}}$ & + &
\end{tabular}

aCalibrated radiocarbon dates, in years before present; ${ }^{\text {NN}}$ ot determined by radiocarbon dating, but defined on archaeological grounds; ${ }^{\text {Broglio }}$ and Improta (1994-95); 35 dUniversity of Utrecht, 1998; eUniversity of Zurich, 1997. 
giving no indication of contamination by exogenous amino acids.

The amount of DNA retrieved varies among the five specimens (Table2). One sample, Fiavè, contained no amplifiable DNA in several independent extracts. The extracts of the Vatte specimen contained too few template molecules to provide reproducible results. This lack of reproducibility probably reflects low-level, sporadic contamination, as well as Taq errors in the first cycles of the PCR, which may predominate the $P C R$ reaction if there are only a few template molecules. ${ }^{20,23}$ However, the Mezzocorona, Villabruna, and Borgu Nuovo specimens yiel ded several thousand molecules for each amplification, as judged by quantitative PCR using a competitor construct. An example of a quantitation experiment, both from a tooth and a jaw bone of one individual, as in Figure2. As expected, the tooth yielded more DNA for equal amounts of tissue.

Ancient DNA molecules tend to be damaged, so that amplifications of fragments longer than $100-200 \mathrm{bp}$ are difficult (if not impossible). We therefore decided to recon-

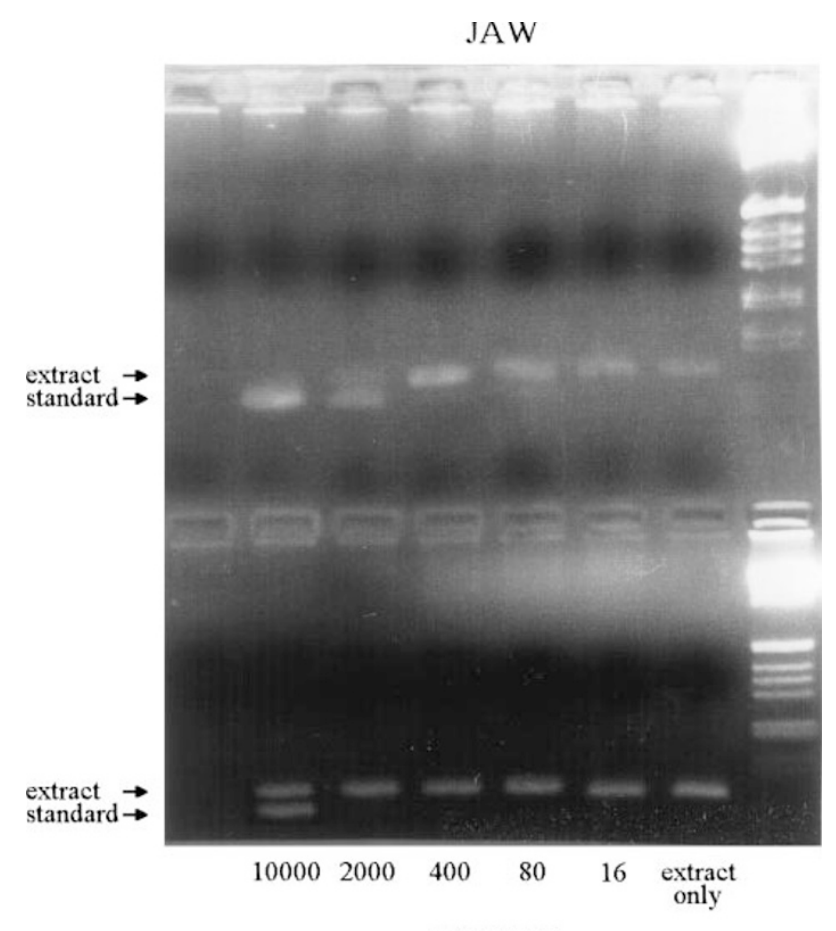

TOOTH

Figure 2 DNA quantitation. Example of quantitation of the DNA. Two extracts from the same individual (Mezzocorona), one from the jaw and one from a tooth, are compared. The pictures show that the jaw extract contains about 2000 molecules $/ 2.5 \mu \mathrm{l}$ (volume added to each PCR), whereas the tooth extract contains about 10000 (or more) molecules. The latter was used in setting up the PCRs. Both extracts contained 0.1 grams of tissue. struct the mtDNA HVR I sequence for the Mezzocorona, Villabruna, and Borgo Nuovo samples by amplification of five short overlapping fragments. For each specimen and for each region amplified, several clones were sequenced. All steps of the analysis described hereafter were repeated at least twice (once for each of the two extracts) in a European laboratory, Munich (extractions and amplifications) or Ferrara (only sequencing). All DNAs were also independently extracted from a different tooth of the same individual in the Penn State laboratory, and sequenced for all $360 \mathrm{bp}$, or part thereof.

For the Mezzocorona specimen, all clone sequences were in perfect agreement among and within the different extracts; the Borgo Nuovo and Villabruna sequences were not always identical in all extracts, but they differ for single-base substitutions that occur only in the clones of just one amplification. Therefore, it is possible to infer the endogenous sequence with a high level of confidence by comparing the sequences obtained from different extracts. The complete results including all the clones sequenced are shown in Figures34-5, while Table3 summarises the final results for the three individuals. Substitutions at sites 16126, 16292, and 16294 (relative to the published reference sequence ${ }^{25}$ ) were observed in the Mezzocorona sample, and at sites 16261 and 16274 in the Villabruna sample, whereas the Borgo Nuovo sequence was identical to the reference sequence.

Together with the sequence from the 5200 year-old 'ice man', ${ }^{26}$ the sequences described these are the only European prehistoric mtDNA sequences determined to date. To investigate further the affinities of these four sequences, we calculated the mean number of pairwise sequence differences (MPSD) between each of them and several population samples (Table4). Three main features are apparent from this analysis. First, for each specimen the MPSD is clearly lower (values are more than 1.96 standard errors apart) for Europe and for Africa or Asia. Second, when Europe is divided into three regions (Mediterranean, Northern, and Alps), there is essentially no difference between the MPSD values for each of the three regions with each of the prehistoric sequences, in agreement with studies showing that most genetic differences occur within, rather than between, European populations. $^{27}$ Third, all the neolithic sequences have also been observed in contemporary samples, whereas the single mesolithic sequence (Villabruna) has not been observed to date in any living individual. Absence of evidence is not evidence of absence; however, in a broad database of 2600 European mitochondrial sequences ${ }^{27}$ we found 11 sequences with only substitution 16261 (four of them Swiss, two Germans, and one Italian-speaker from the Alps), and three sequences with only one substitution 16274 . The only sequence showing both substitutions observed in the Villabruna specimen also has transitions at 16069, 16126, 16145 and 16222, and falls within a different haplogroup, J. 


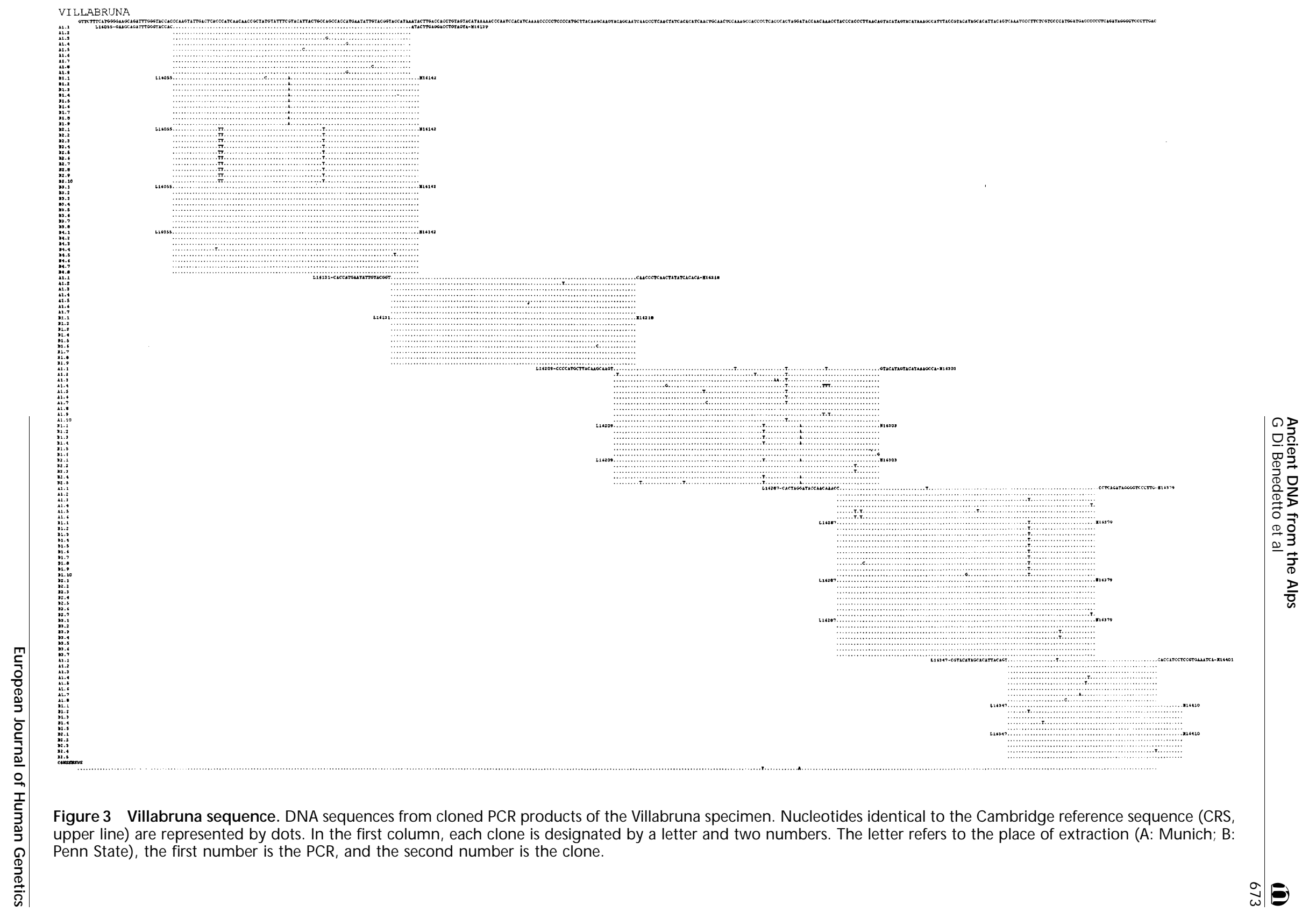




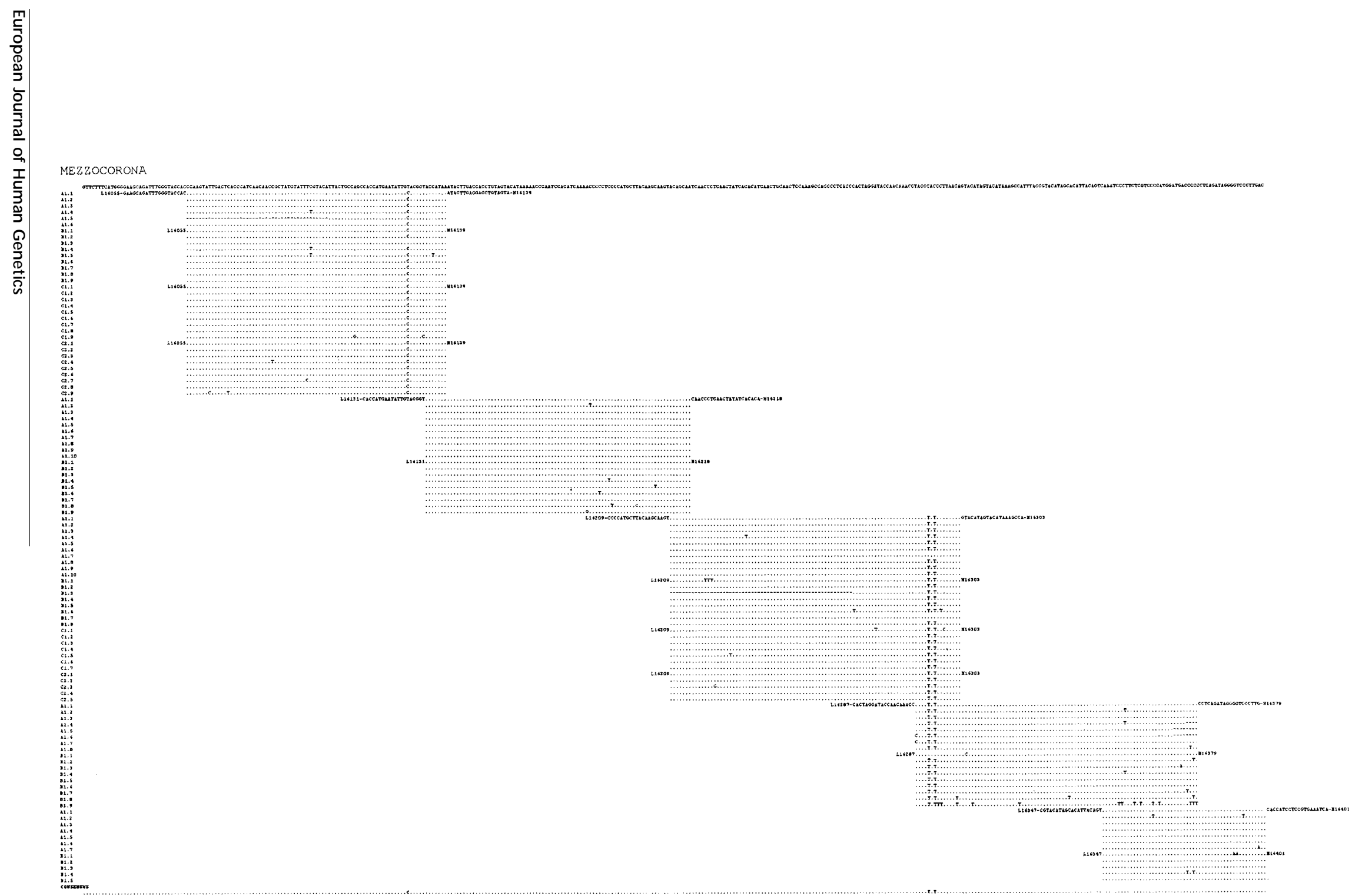

Figure4 Mezzocorona sequence. DNA sequences from cloned PCR products of the Mezzocorona specimen. The letter refers to the place of extraction (A, B: Munich C: Penn State), the first number is PCR, and the second number is the clone. 


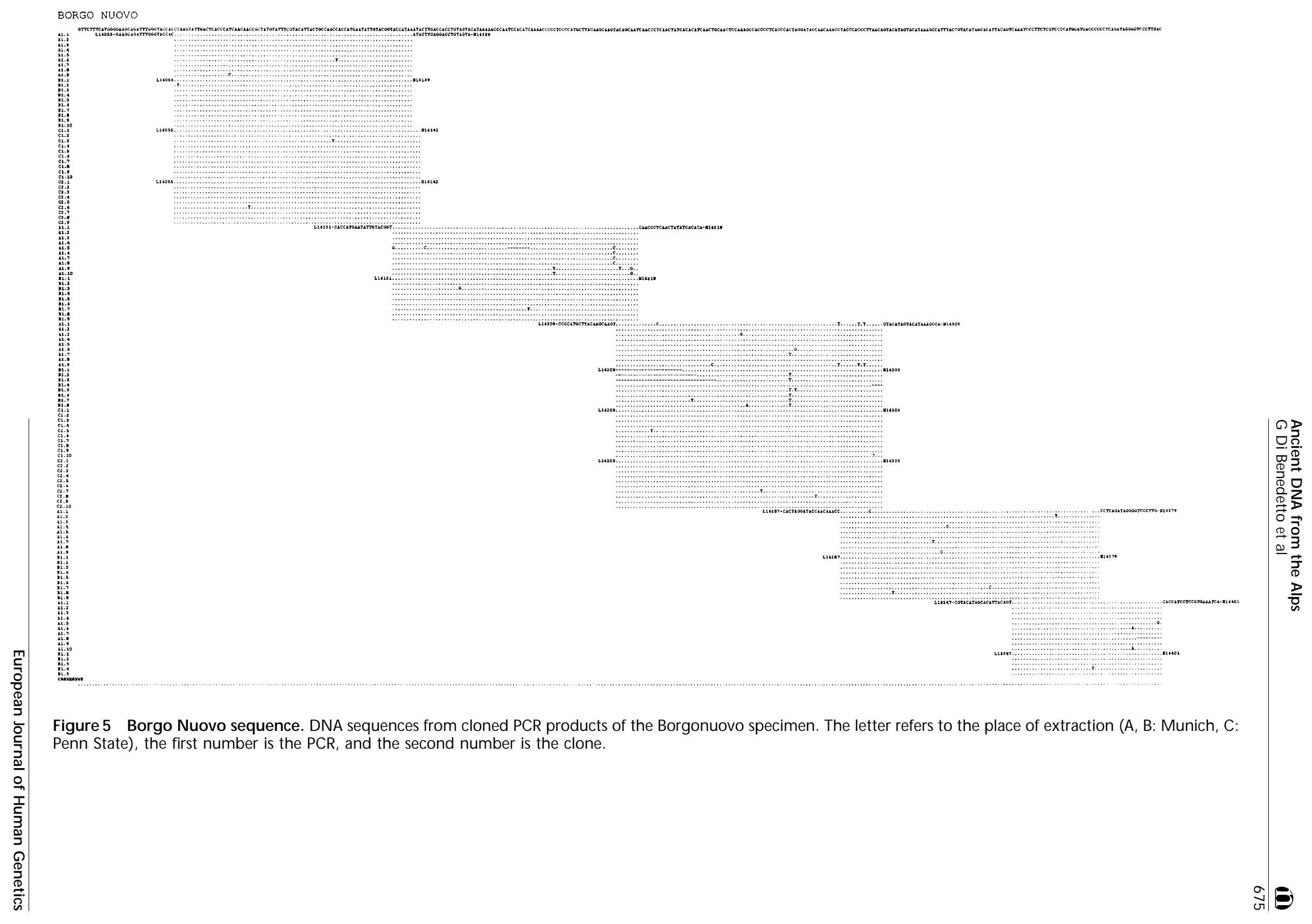


Table 3 Summary of the mitochondial characterisation of the three samples sequenced

\begin{tabular}{llll}
\hline Sample & $\begin{array}{l}\text { Substitutions } \\
\text { with respect to CRS }\end{array}$ & $\begin{array}{l}\text { Haplogroup } \\
\text { (Richards et al }^{4} \text { ) }\end{array}$ & $\begin{array}{l}\text { Haplogroup } \\
\text { (Torroni et al }^{32} \text { ) }\end{array}$ \\
\hline Mezzocorona & $\begin{array}{l}16126,16292, \\
16294\end{array}$ & $2 \mathrm{~B}$ & $\mathrm{~T}$ \\
Villabruna & $\begin{array}{l}16261,16274 \\
\text { Borgo Nuovo }\end{array}$ & 1 & $\mathrm{H}$ \\
\hline
\end{tabular}

\section{Discussion}

The three mtDNA sequences described here, together with the 'ice man' sequence, ${ }^{26}$ are the only prehistoric European mtDNA sequences determined to date. This small sample size reflects, at least to some extent, the great difficulty in authenticating DNA extracted from ancient human remains (particularly when the remains are from the same geographic region as the people performing the analysis). The large amount of effort that has gone into obtaining the sequences reported here (ie reconstruction of each 360-bp sequence from clones of five overlapping PCR products) and ensuring their authenticity (including rigorous controls to detect contamination, multiple extractions from the same sample, and independent analysis in another laboratory), guarantees that sample sizes for such studies will remain small.

Nonetheless, these four sequences provide some insight into prehistoric European mtDNA diversity. The three neolithic sequences have a mean pairwise difference (MPSD) of 3.3, whereas estimates from contemporary sequences from comparable regions fall between 1.9 and 7.0. ${ }^{28,29}$ Although these neolithic sequences range in age from 5200 to about 6400 years, this suggests that the mtDNA diversity in Europe was not much different in the neolithic period than it is at present. Analysis of mtDNA restriction site polymorphisms in 3000-5000-year-old remains from I beria leads to the same conclusion. ${ }^{30}$ Moreover, sequences identical to those determined in our neolithic samples are observed over much of Europe (Table4). In particular, the Borgo Nuovo and 'ice man' sequences are fairly common all across Europe, whereas the rarer Mezzocorona sequence is documented not far from the Alps, in Germany, ${ }^{5}$ and closely related sequences are widespread in Europe. These results suggest that there has been some degree of continuity between the early neolithic and present-day inhabitants of Europe.

In contrast to the Neolithic sequences, the one Mesolithic sequence (Villabruna) has not been observed in any individual from the present day sample of over 2600 Europeans. ${ }^{27}$ Villabruna's cl osest relatives differ by 1 substitution, but they are closer to the root of the mtDNA tree than is Villabruna. One other sequence (from Tuscany) has the 16261 and 16274 substitutions, and four more, two of them occurring near the root of the tree ${ }^{31}$ and characterising haplogroup J. It seems that either the Villabruna sequence has left very few descendants, if any, in contemporary Europe, or that these descendants differ by a retro-mutation. This result may thus be an indication of a genealogical discordancy between mesolithic and present-day inhabitants of Europe, although obviously additional mesolithic sequences are needed to gain an accurate picture of the relationship between mesolithic and present-day Europe.

Other workers have designated mtDNA haplogroups (clusters of related mtDNA types) based on HVR I sequences ${ }^{4}$ or on restriction site polymorphisms of the entire mitochondrial genome, $^{31,32}$ and used these to classify European mtDNAs. Since the substitutions we observed in HVR I have been shown to be associated with specific restriction patterns, ${ }^{7,31}$ we can assign the prehistoric sequences to haplogroups with a good degree of confidence. The Mezzocorona sequence, with substitutions at 16126 and 16294, falls into haplogroup $\mathrm{T}$, whereas the Borgo Nuovo and Villabruna sequences fall into haplogroup $\mathrm{H}$, and the 'ice man' sequence belongs to haplogroup $\mathrm{K}$. Thus, each neolithic sequence falls into a different haplogroup, further testifying to the high level of mtDNA diversity in the Alps at the beginning of the neolithic period. And these three haplogroups are among the most common in Europe today, with overall frequencies (estimated by Macaulay et $\mathrm{al}^{31}$ ) of $50 \%$ for $\mathrm{H}, 8 \%$ for $\mathrm{T}$, and $7 \%$ for $\mathrm{K}$. The fact that haplogroups that are common in Europe today are also found at the beginning of the neolithic period further supports a gen ealogical continuity in Europe between the neolithic period and the present.

Such continuity is of particular interest for understanding genetic variation in the Ladin-speaking communities of the eastern Italian Alps, who are quite distinct from other

Table 4 Mean pairwise sequence differences (MPSD) and standard errors (SD) between four prehistoric mtDNA sequences and sequences from contemporary populations

\begin{tabular}{|c|c|c|c|c|c|c|c|c|c|c|c|c|c|}
\hline \multirow[b]{2}{*}{ Population } & \multirow[b]{2}{*}{$\begin{array}{l}\text { Sample } \\
\text { size }\end{array}$} & \multicolumn{3}{|c|}{$\begin{array}{c}\text { Villabruna } \\
13831-14267 \text { BP }\end{array}$} & \multicolumn{3}{|c|}{$\begin{array}{l}\text { Borgo Nuovo } \\
5930-6240 \text { BP }\end{array}$} & \multicolumn{3}{|c|}{$\begin{array}{l}\text { Mezzocorona } \\
6326-6444 \text { BP }\end{array}$} & \multicolumn{3}{|c|}{$\begin{array}{c}\text { Ice man (Handt et } \mathrm{al}^{26} \text { ) } \\
5200 \mathrm{BP}\end{array}$} \\
\hline & & MPSD & SD & $\begin{array}{l}\text { Shared } \\
\text { sequences }\end{array}$ & MPSD & SD & $\begin{array}{l}\text { Shared } \\
\text { sequences }\end{array}$ & MPSD & SD & $\begin{array}{l}\text { Shared } \\
\text { sequences }\end{array}$ & MPSD & SD & $\begin{array}{l}\text { Shared } \\
\text { sequences }\end{array}$ \\
\hline$\overline{\text { Africa }}$ & 302 & 8.35 & 2.13 & 0 & 6.33 & 2.24 & 9 & 8.58 & 2.05 & 0 & 7.32 & 1.67 & 1 \\
\hline Asia & 730 & 5.25 & 0.85 & 0 & 3.42 & 0.84 & 47 & 5.99 & 1.01 & 1 & 5.38 & 0.93 & 6 \\
\hline Europe & 2382 & 4.18 & 0.37 & 0 & 2.28 & 0.39 & 342 & 4.66 & 0.34 & 3 & 3.86 & 0.42 & 55 \\
\hline Mediterranean Europe & 674 & 4.10 & 0.39 & 0 & 2.18 & 0.44 & 137 & 4.60 & 0.30 & 2 & 3.86 & 0.49 & 13 \\
\hline Northern Europe & 623 & 4.07 & 0.33 & 0 & 2.19 & 0.34 & 84 & 4.56 & 0.28 & 1 & 3.75 & 0.42 & 16 \\
\hline Alps & 653 & 4.29 & 0.45 & 0 & 2.42 & 0.40 & 84 & 4.76 & 0.20 & 0 & 3.84 & 0.40 & 20 \\
\hline
\end{tabular}


European groups with respect to mtDNA. ${ }^{29}$ This distinctiveness is largely due to high frequencies (up to $70 \%$ ) of haplogroup $\mathrm{T}$ sequences in the Ladins, ${ }^{29,33}$ which are much less frequent ( $<13 \%$ ) elsewhere in Europe. Our results for the Mezzocorona sample demonstrate that haplogroup $\mathrm{T}$ was present in the Alps about 6300 years ago. Since the Ladin language is thought to have developed no more than 1500 years ago, ${ }^{34}$ and if the current genetic structure of the Ladins was established by the beginning of the neolithic period (or even earlier), factors other than linguistic differentiation must account for the high frequency of haplogroup $\mathrm{T}$ in the ancestors of the Ladins. Geographical barriers are obvious candidates.

\section{Acknowledgements}

Loredana Nigro passed away while we were writing this manuscript. We shall always miss her intelligence, her wit, and her charm. This study was supported by the Italian National Research council grant 96.01182.PF36, and by the Italian Ministry of the Universities Fund 'COFIN 99' to GB. GDB was partly supported by a grant from Fondazione della Cassa di Risparmio di Trento e Rovereto, and MK held a stipend from the Boehringer Ingel heim Fonds. Work in the Penn State laboratory was supported by a grant from the National Science Foundation to MS. We thank Jaume Bertranpetit and Lucia Simoni for giving us access to unpublished sequence data, and Alberto Broglio for fruitful discussions on the prehistory of the Alps.

\section{References}

1 Mellars PA: Archaeology and the population dispersal hypothesis of modern human origins in Europe. Phil Trans Royal Soc London B 1992; 337: 225-234.

2 Stringer $C$ : The origin of early modern humans: A comparison of the European and non-European evidence. In: Mellars P, Stringer C (eds). The Human Revolution. Edinburgh University Press: Edinburgh, 1989, pp 232-244.

3 Otte M: The northwestern European plain around 18,000 BP. In: Soffer O, Gamble C (eds). The World at 18,000 BP, vol. 1. Unwin Hyman: London, 1990, pp 54-68.

4 Richards M, Corte-Real H, Forster P et al: Pal eolithic and Neolithic lineages in the European mitochondrial gene pool. Am J Hum Genet 1996; 59: 185-203.

5 Richards M, Macaulay V, Sykes B et al: Palaeolithic and Neolithic lineages in the European mitochondrial gene pool: a response to Cavalli-Sforza and Minch. Am J Hum Genet 1997; 61: 251-254.

6 Richards M, Macaulay VA, Bandelt HJ, Sykes BC: Phylogeography of mitochondrial DNA in western Europe. Ann Hum Genet 1998; 62: 241-260.

7 Torroni A, Bandelt HJ, D'Urbano L et al: MtDNA analysis reveals a major late Paleolithic expansion from southwestern to northeastern Europe. Am J Hum Genet 1998; 62: 1137-1152.

8 Sykes B: The molecular genetics of European ancestry. Phil Trans R Soc London B 1999; 354: 131-139.

9 Menozzi P, Piazza A, Cavalli-Sforza LL: Synthetic maps of human gene frequencies in Europeans. Science 1978; 201: 786-792.

10 Sokal RR, Menozzi P: Spatial autocorrelation of HLA frequencies in Europe supports demic diffusion of early farmers. Am Nat 1982; 119: 1-17.

11 Ammerman AJ, Cavalli-Sforza LL: The Neolithic Transition and the Genetics of Populations in Europe. Princeton University Press: Princeton, NJ, 1984.

12 Renfrew C: Archaeology and Language. The Puzzle of Indo-European Origins. Jonathan Cape: London, 1987.
13 Sokal RR, Oden NL, Wilson C: New genetic evidence for the spread of agriculture in Europe by demic diffusion. Nature 1991; 351: 143-145.

14 Cavalli-Sforza LL, Minch E: Paleolithic and Neolithic lineages in the European mitochondrial gene pool. Am J Hum Genet 1997; 61: 247-251.

15 Barbujani G, Bertorelle G, Chikhi L: Evidence for Paleolithic and Neolithic gene flow in Europe. Am J Hum Genet 1998; 62: 448-491.

16 Chikhi L, Destro-Bisol G, Bertorelle G, Pascali V, Barbujani G: Clines of nuclear DNA markers suggest a largely Neolithic ancestry of the European gene pool. Proc Natl Acad Sci USA 1998; 95: 9053-9058.

17 Chikhi L, Destro-Bisol G, Pascali V, Baravelli V, Dobosz M, Barbujani G: Clinal variation in the DNA of Europeans. Hum Biol 1998; 70: 643-657.

18 Bisi F, Broglio A, Dalmeri G, Lanzinger M, Sartorelli A: Les bases Mésolithiques du Néolithique ancien au sud des Alpes. In: Kozlowski JK, Koslowski SK (eds). Chipped Stone Industries of the Early Farming Cultures in Europe. Archaeologia Interregionalis: Warsaw, 1987; pp 381-422.

19 Poinar HN, Hoss M, Bada JL, Pääbo S: Amino acid racemization and the preservation of ancient DNA. Science 1996; 272: 864-866.

20 Krings M, Stone A, Schmitz RW, Krainitzki H, Stoneking M, Pääbo $\mathrm{S}$ : Neandertal DNA sequences and the origin of modern humans. Cell 1997; 90: 19-30.

21 Stone AC, Stoneking M: mtDNA analysis of a prehistoric Oneota population: Implications for the peopling of the new world. Am J Hum Genet 1998; 62: 1153-1170.

22 Ausubel FA, Brent R, Kingston RE et al: Current Protocols in Molecular Biology. John Wiley \& Sons: New York, 1995.

23 Handt O, Krings M, Ward RM, Pääbo S: The retrieval of ancient human DNA sequences. Am J Hum Genet 1996; 59: 368-376.

24 Forster E: An improved general method to generate internal standards for competitive PCR. Biotechniques 1994; 16: 18-20.

25 Anderson S, Bankier T, Barrel BG et al: Sequence and organization of the human mitochondrial genome. Nature 1981; 290 457-465.

26 Handt $\mathrm{O}$, Richards $M$, Trommsdorff $M$ et al: Molecular genetic analyses of the Tyrolean Ice Man. Science 1994; 264: 1775-1778.

27 Simoni L, Calafell F, Pettener D, Bertranpetit J, Barbujani G: Geographic patterns of mt-DNA diversity in Europe. Am J Hum Genet 2000; 66: 262-278.

28 Pult I, Sajantila A, Simanainen J, Georgiev O, Scaffner W, Pääbo S: Mitochondrial DNA sequences from Switzerland reveal striking homogeneity of European populations. Biol Chem Hoppe-Seyler 1994; 375: 837-840.

29 Stenico M, Nigro L, Bertorelle $G$ et al: High mitochondrial sequence diversity in linguistic isolates of the Alps. Am J Hum Genet 1996; 59: 1363-1375.

30 Izagirre N, de la Rua C: An mtDNA analysis in ancient Basque populations: implications for haplogroup $\mathrm{V}$ as a marker for a major paleolithic expansion from southwestern Europe. Am J Hum Genet 1999; 65: 199-207.

31 Macaulay V, Richards M, Hickey E et al: The emerging tree of west Eurasian mtDNAs: A synthesis of control-region sequences and RFLPs. Am J Hum Genet 1999; 64: 232-249.

32 Torroni A, Huoponen K, Francalacci $\mathrm{P}$ et al: Classification of European mtDNAs from an analysis of three European populations. Genetics 1996; 144: 1835-1850.

33 Stenico M, Nigro L, Barbujani G: Mitochondrial lineages in Ladinspeaking communities of the eastern Alps. Proc Royal Soc B 1998; 265: 555-561.

34 Pulgram E: Italic, Latin, Italian. Winter: Heidelberg, 1978.

35 Broglio A, Improta S: Nuovi dati sulla cronlogia assoluta del paleolitico superiore e del mesolitico del Veneto, del Trentino e del Friuli. Atti Ist Ven Scienze Lettere ed Arti 1994-95; 153: 1-45. 